\title{
EFEKTIVITAS PENAMBAHAN SARI KURMA DALAM PEMENUHAN GIZI IBU HAMIL ANEMIA DI PUSKESMAS WEDI, KABUPATEN KLATEN
}

\author{
RD Rahayu \\ Kementerian Kesehatan Politeknik Kesehatan Surakarta Jurusan Kebidanan
}

\begin{abstract}
Sarikurma, Pregnancy, Anemia, Hemoglobin. Dates also have many benefits including increasing the number of platelets, preventing blood clots, prevent strokes and heart attacks, prevent uterine bleeding, thin brain during fasting, increase energy, hindering the process of aging, prevent constipation and smooth bowel movement, reduce blood cholesterol, keeping eye health and good for the nervous system. Aim. To determine the effectiveness of the addition of palm juice against anemia in pregnant women at health centers Wedi Klaten district. This type of research is experimental, quasi-experimental approach, using a pretest-posttest control group design. population $(N)=303$ people, found the number of samples (S) as many as 50 people. Of the 50 people, will be divided into two equal groups, 25 people will be used as the treatment group (giving palm juice) and 25 will be used as the control group (without a date palm juice). In the group without extract dates, respondents consumed MMN. Data were analyzed using t-test. Results. Anemia hemoglobin levels of pregnant women who were given MMN average was 10.4 $\mathrm{mmHg}$. Hemoglobin levels of pregnant women are anemic before given Sarikurma average of 10.38 and after Sarikurma by an average of 10.84. Conclusion. Sarikurma more effective compared to MMN with $p=0.045(p<0.05)$.
\end{abstract}

Keywords: Sarikurma, Pregnancy, Anemia, Hemoglobin

Abstrak: Sarikurma, Ibu Hamil, Anemia, Kadar Hemoglobin. Kurma juga mempunyai banyak manfaat diantaranya meningkatkan jumlah trombosit, mencegah pembekuan darah, mencegah stroke dan serangan jantung, mencegah perdarahan rahim, otak encer selama berpuasa, menambah tenaga, menghambat proses penuaaan, mencegah sembelit dan melancarkan buang air besar, menurunkan kolesterol dalam darah, menjaga kesehatan mata dan baik untuk sistem syaraf. Tujuan untuk mengetahui efektivitas penambahan sari kurma terhadap ibu hamil anemia di Puskesmas Wedi di Kabupaten Klaten. Jenis penelitian ini adalah eksperiment, dengan pendekatan kuasi experimental, menggunakan rancangan pretest-posttest control group design. populasi $(\mathrm{N})=303$ orang, didapatkan jumlah sampel (S) sebanyak 50 orang. Dari 50 orang, akan dibagi menjadi dua kelompok sama rata, 25 orang akan dijadikan kelompok perlakuan (pemberian sari kurma) dan 25 orang akan dijadikan kelompok control (tanpa sari kurma). Pada kelompok tanpa sari kurma, responden mengkonsumsi MMN. Analisa data menggunakan t-test. Hasil. Kadar hemoglobin ibu hamil anemia yang diberi MMN rata-rata adalah 10,4 mmHg. Kadar hemoglobin ibu hamil anemia yang sebelum diberi sarikurma rata-rata 10,38 dan sesudah diberi sarikurma rata-rata 10,84. Kesimpulan. Sarikurma lebih efektif dibandingkan dengan MMN dengan nilai $\mathrm{p}=0,045(\mathrm{p}<0,05)$.

Kata Kunci : Sarikurma, Ibu Hamil, Anemia, Kadar Hemoglobin 


\section{PENDAHULUAN}

Anemia merupakan masalah kesehatan masyarakat di seluruh dunia. Lebih dari setengah penduduk dunia khususnya anak belum sekolah dan ibu hamil di beberapa negara mengalami anemia (Mc.Lean E, 2007). World Health Organization (WHO) melaporkan bahwa terdapat $52 \%$ ibu hamil mengalami anemia di negara berkembang (Fatimah, 2011). Di Indonesia prevalensi anemia pada ibu hamil menurut SKRT masih cukup tinggi yaitu 40,1\%. Hasil Riset Kesehatan Dasar menunjukkan $80,7 \%$ perempuan usia $10-59$ tahun telah mendapatkan tablet tambah darah yang mengandung besi-asam folat. Meskipun demikianangka kejadian anemia pada ibu hamil masih mencapai $40-50 \%$, artinya 5 dari 10 ibu hamil di Indonesia mengalami anemia (Kemenkes RI, 2013).

Salah satu penyebab tingginya prevalensi anemia pada ibu hamil yaitu kebutuhan zat besi yang meningkat akibat perubahan fisiologi dan metabolisme pada ibu, inadequate intake (utamanya zat besi, dan juga defisiensi asam folat dan vitamin B12), gangguan penyerapan, infeksi (malaria dan kecacingan), kehamilan yang berulang, thalasemia dan sickle cell disease, kondisi sosial, ekonomi, budaya dan pendidikan ibu (Hidah, 2009).

Upaya pembangunan kesehatan gizi masyarakat sebagai bagian dari program pembangunan nasional merupakan salah satu strategi yang tepat untuk dilaksanakan saat ini. Yang bertujuan untuk mewujudkan derajat kesehatan dan gizi masyarakat yang optimal, dimana salah satu program yang akan dicapai adalah menurunkan prevalensi empat masalah gizi utama yang ada di Indonesia, yang salah satunya adalah Anemia Gizi besi (AGB) (Sinaga, 2005). Haemoglobin adalah molekul protein yang mengangkut sel darah merah sebagai media transportasi $\mathrm{O} 2$, Haemoglobin dibentuk dalam sel darah merah pada sumsum tulang belakang,dan kegagalan pembentukan haemoglobin dapat disebabkan karena kekurangan protein. Faktor pembentuk hemoglobin seperti Fe, B12 dan, asam folat semuanya terdapat dalam kurma.

Berdasarkan studi pendahuluan yang kami lakukan, pada periode Januari sampai dengan Juni 2015 dari 34 Puskesmas di Kabupaten Klaten terdapat sejumlah 6977 ibu hamil yang dilakukan pemeriksaan hemoglobin dengan hasil ibu hamil yang mengalami anemia 1857 orang (8-11 gr\%) dan 52 orang $(<8$ gr\%). Dari data tersebut puskesmas yang menduduki peringkat I untuk ibu hamil anemia berada di puskesmas wedi yaitu sebanyak 148 orang dari 303 orang ibu hamil (Dinas Kesehatan Klaten, 2015).

Berdasarkan fenomena-fenomena tersebut maka penulis merasa tertarik untuk melakukan penelitian tentang "Efektivitas Penambahan Sari Kurma dalam Pemenuhan Gizi Ibu Hamil Anemia di Puskesmas Wedi Kabupaten Klaten".

\section{METODE PENELITIAN}

Jenis penelitian ini adalah observasional. Pemantauan dilakukan setiap minggu. Random sampling dilakukan setelah didapatkan sampel secara purposive. Penentuan besar sampel berdasarkan tabel Cohen Manion dan Morisson (2007) dengan taraf signifikansi 95\%. Pada populasi $(\mathrm{N})=303$ orang, didapatkan jumlah sampel (S) sebanyak 50 orang. Dari 50 orang, akan dibagi menjadi dua kelompok sama rata, 25 orang akan dijadikan kelompok perlakuan (pemberian sari kurma) dan 25 orang akan dijadikan kelompok control (tanpa sari kurma). Pada kelompok tanpa sari kurma, responden 
mengkonsumsi MMN. Sebelum dilakukan uji hipotesis, dilakukan uji prasyarat. Uji chi square.

\section{HASIL PENELITIAN}

1. Karakteristik Responden

Karakteristik responden meliputi umur, paritas, pendidikan, pengetahuan, diet dan $\mathrm{Hb}$

Tabel 1

Karakteristik Responden

\begin{tabular}{llll}
\hline & $\mathrm{f}$ & \multicolumn{1}{c}{$\%$} & \multicolumn{1}{c}{ Total } \\
\hline Umur & & & \\
$<20$ tahun & 0 & 0 & 0 \\
$20-35$ tahun & 44 & 88 & $44(88 \%)$ \\
$>35$ tahun & 6 & 12 & $6(12 \%)$ \\
\hline Gravida & & & \\
Primipara & 12 & 24 & $12(24 \%)$ \\
Multipara & 32 & 64 & $32(64 \%)$ \\
Grandemulti & 6 & 12 & $6(12 \%)$ \\
\hline Pendidikan & & & \\
SD & 6 & 12 & $6(12 \%)$ \\
SMP & 6 & 12 & $6(12 \%)$ \\
SMA & 24 & 48 & $24(48 \%)$ \\
PT & 14 & 28 & $14(28 \%)$ \\
\hline Pengetahuan & & & \\
Baik & 28 & 56 & $28(56 \%)$ \\
Cukup & 22 & 44 & $22(44 \%)$ \\
Kurang & 0 & 0 & 0 \\
\hline Diet & & & \\
Baik & 36 & 72 & $36(72 \%)$ \\
Tidak Baik & 14 & 38 & $14(38 \%)$ \\
\hline
\end{tabular}

Berdasarkan tabel 1 diketahui bahwa umur responden sebagian besar adalah produktif yaitu (20-35 tahun) sebanyak 44 responden (88\%). Gravid responden sebagian besar adalah multipara sebanyak 32 responden (64\%). Pendidikan responden sebagian besar adalah SMA sebanyak 24 responden (48\%). Pengetahuan responden sebagian besar adalah baik sebanyak 28 responden (56\%) dan diet pada ibu hamil sebagian besar adalah baik sebanyak 36 responden (72\%).
2. Kadar $\mathrm{Hb}$

Tabel 2

Distribusi Frekuensi Kadar Hemoglobin

\begin{tabular}{lccc}
\hline & $\mathrm{f}$ & $\%$ & Total \\
\hline Kadar Hb & & & \\
Normal & 28 & 56 & $28(56 \%)$ \\
Tidak Normal & 22 & 44 & $22(44 \%)$ \\
\hline
\end{tabular}

Berdasarkan tabel 2 diketahui bahwa sebagian besar responden dengan kadar $\mathrm{Hb}$ normal yaitu 11 gr\% sebanyak 28 orang $(56 \%)$ dan yang tidak normal sebanyak 22 orang (44\%).

3. Faktor-faktor yang mempengaruhi kadar $\mathrm{Hb}$

a. Umur

Tabel 3

Distribusi Faktor umur terhadap kenaikan kadar Hb pada ibu hamil anemia

\begin{tabular}{|c|c|c|c|c|c|c|c|c|}
\hline \multirow{3}{*}{$\begin{array}{c}\text { Umur } \\
\text { (tahun) }\end{array}$} & \multicolumn{4}{|c|}{ Kadar Hb } & \multirow{2}{*}{\multicolumn{2}{|c|}{ Total }} & \multirow{3}{*}{$\chi^{2}$} & \multirow{3}{*}{$\mathbf{p}$} \\
\hline & \multicolumn{2}{|c|}{ Normal } & \multicolumn{2}{|c|}{$\begin{array}{c}\text { Tidak } \\
\text { Normal }\end{array}$} & & & & \\
\hline & f & $\%$ & $\mathbf{f}$ & $\%$ & f & $\%$ & & \\
\hline$<20$ & 0 & 0 & 0 & 0 & 0 & 0 & 2,922 & 0,087 \\
\hline $20-35$ & 27 & 54 & 18 & 36 & 45 & 90 & & \\
\hline$>35$ & 1 & 2 & 4 & 8 & 5 & 10 & & \\
\hline Jumlah & 28 & 56 & 22 & 44 & 50 & 100 & & \\
\hline
\end{tabular}

diketahui bahwa responden pada umur 2035 tahun dengan kadar $\mathrm{Hb}$ normal sebanyak 27 orang (54\%) dan tidak normal sebanyak 18 orang $(36 \%)$ dari jumlah total 45 responden). Hasil uji statistic dengan chi square didapatkan hasil bahwa nilai $\mathrm{p}=$ 0,087 ( $\mathrm{p}>0,05$ ) jadi tidak ada hubungan umur ibu terhadap kenaikan kadar $\mathrm{Hb}$ ibu hamil anemia. 
b. Gravida

Tabel 4

Distribusi Faktor Gravida Terhadap Kenaikan Kadar Hb Pada Ibu Hamil Anemia

\begin{tabular}{lcccccccc}
\hline \multirow{2}{*}{$\begin{array}{c}\text { Gravid } \\
\text { a }\end{array}$} & \multicolumn{9}{c}{ Kadar Hb } & \multicolumn{1}{c}{$\begin{array}{c}\text { Norm } \\
\text { al }\end{array}$} & $\begin{array}{c}\text { Tidak } \\
\text { Norm } \\
\text { al }\end{array}$ & Total & & \multirow{2}{*}{$\boldsymbol{\chi}^{\mathbf{2}}$} & $\mathbf{p}$ \\
\cline { 2 - 6 } & $\mathbf{f}$ & $\mathbf{\%}$ & $\mathbf{f}$ & $\mathbf{\%}$ & $\mathbf{f}$ & $\mathbf{\%}$ & & \\
\hline Primip & 1 & 2 & 0 & 0 & 1 & 24 & 5,14 & 0,00 \\
ara & 2 & 4 & 1 & 3 & 2 & 64 & 6 & 6 \\
Multip & 1 & 3 & 6 & 2 & 3 & 12 & & \\
ara & 6 & 2 & 6 & 1 & 3 & & & \\
Grande & 0 & 0 & & 2 & 6 & & & \\
\hline Jumlah & 2 & 5 & 2 & 4 & 5 & 10 & & \\
& 8 & 6 & 2 & 4 & 0 & 0 & & \\
\hline
\end{tabular}

Berdasarkan hasil tabel 4 diketahui bahwa responden dengan paritas primipara sebanyak 12 orang dengan kadar $\mathrm{Hb}$ normal, multipara dengan kadar $\mathrm{Hb}$ normal sebanyak 16 responden (32\%). Hasil uji statistic dengan chi square didapatkan hasil bahwa nilai $\mathrm{p}=0,006(\mathrm{p}<0,05)$ jadi ada hubungan gravida terhadap kenaikan kadar $\mathrm{Hb}$ ibu hamil anemia.

c. Pendidikan

\section{Tabel 5}

Distribusi Faktor Pendidikan Terhadap Kenaikan Kadar HB Pada Ibu Hamil

\begin{tabular}{lcccccccc}
\hline & \multicolumn{9}{c}{ Kadar Hb } & & & \\
\cline { 2 - 6 } $\begin{array}{c}\text { Pendidi } \\
\text { kan }\end{array}$ & $\begin{array}{c}\text { Norm } \\
\text { al }\end{array}$ & $\begin{array}{c}\text { Tidak } \\
\text { Norm } \\
\end{array}$ & al & Total & & \multirow{2}{*}{$\chi^{2}$} & $\mathrm{p}$ \\
\cline { 2 - 6 } & $\mathrm{f}$ & $\%$ & $\mathrm{f}$ & $\%$ & $\mathrm{f}$ & $\%$ & & \\
\hline SD & 1 & 2 & 5 & 1 & 6 & 12 & 20,3 & 0,0 \\
SMP & 3 & 6 & 3 & 0 & 6 & 12 & 11 & 00 \\
SMA & 2 & 4 & 3 & 6 & 2 & 48 & & \\
PT & 1 & 2 & 1 & 6 & 4 & 28 & & \\
& 3 & 6 & & 2 & 1 & & & \\
& & & & 2 & 4 & & & \\
\hline Jumlah & 2 & 5 & 2 & 4 & 5 & 10 & & \\
& 8 & 6 & 2 & 4 & 0 & 0 & & \\
\hline
\end{tabular}

Berdasarkan hasil tabel 5 diketahui bahwa responden dengan pendidikan SD yang kadar $\mathrm{Hb}$ normal sebanyak 1 orang
(2\%), SMP sebanyak 3 orang 96\%), SMA sebanyak 21 orang (42\%) dan PT sebanyak 3 orang $(6 \%)$. Hasil uji statistik dengan chi square didapatkan hasil bahwa nilai $\mathrm{p}=$ $0,000 \quad(\mathrm{p}<0,05)$ jadi ada hubungan pendidikan terhadap kenaikan kadar $\mathrm{Hb}$ ibu hamil anemia.

d. Pengetahuan

Tabel 6

Distribusi Faktor Pengetahuanr

Terhadap Kenaikan Kadar HB Pada Ibu Hamil Anemia

\begin{tabular}{|c|c|c|c|c|c|c|c|c|}
\hline \multirow{3}{*}{$\begin{array}{l}\text { Pengetah } \\
\text { uan }\end{array}$} & \multicolumn{4}{|c|}{ Kadar Hb } & \multirow{2}{*}{\multicolumn{2}{|c|}{ Total }} & \multirow{3}{*}{$\chi^{2}$} & \multirow{3}{*}{$\mathrm{p}$} \\
\hline & \multicolumn{2}{|c|}{$\begin{array}{l}\text { Norm } \\
\text { al }\end{array}$} & \multicolumn{2}{|c|}{$\begin{array}{c}\text { Tidak } \\
\text { Norm } \\
\text { al } \\
\end{array}$} & & & & \\
\hline & $\mathrm{f}$ & $\%$ & $\mathrm{f}$ & $\%$ & f & $\%$ & & \\
\hline Baik & 2 & 5 & 3 & 6 & 2 & 56 & 5,1 & 0,0 \\
\hline Cukup & 5 & 0 & 1 & 3 & 8 & 44 & 52 & 06 \\
\hline \multirow[t]{3}{*}{ Kurang } & 3 & 6 & 9 & 8 & 2 & 0 & & \\
\hline & 0 & 0 & 0 & 0 & 2 & & & \\
\hline & & & & & 0 & & & \\
\hline \multirow[t]{2}{*}{ Jumlah } & 2 & 5 & 2 & 4 & 5 & 10 & & \\
\hline & 8 & 6 & 2 & 4 & 0 & 0 & & \\
\hline
\end{tabular}

Berdasarkan hasil table 6 diketahui bahwa responden dengan pengetahuan baik sebanyak 25 responden (50\%) dengan kadar $\mathrm{Hb}$ normal dan pengetahuan cukup sebnayak 3 orang (6\%). Hasil uji statistic dengan chi square didapatkan hasil bahwa nilai $\mathrm{p}=0,006$ jadi ada hubungan pengetahuan terhadap kenaikan kadar $\mathrm{Hb}$ ibu hamil anemia.

e. Diet

Tabel 7

Distribusi Faktor Diet Terhadap Kenaikan Kadar Hb Pada Ibu Hamil Anemia

\begin{tabular}{|c|c|c|c|c|c|c|c|c|}
\hline \multirow{3}{*}{ Diet } & \multicolumn{4}{|c|}{ Kadar $\mathrm{Hb}$} & \multirow{2}{*}{\multicolumn{2}{|c|}{ Total }} & \multirow{3}{*}{$\chi^{2}$} & \multirow{3}{*}{$\mathrm{p}$} \\
\hline & \multicolumn{2}{|c|}{ Normal } & \multicolumn{2}{|c|}{$\begin{array}{c}\text { Tidak } \\
\text { Normal }\end{array}$} & & & & \\
\hline & $\mathrm{f}$ & $\%$ & $\mathrm{f}$ & $\%$ & $\mathrm{f}$ & $\%$ & & \\
\hline Baik & 19 & 38 & 17 & 34 & 36 & 72 & 0,542 & 0,462 \\
\hline Tidak & 9 & 28 & 5 & 10 & 14 & 28 & & \\
\hline Jumlah & 28 & 56 & 22 & 44 & 50 & 100 & & \\
\hline
\end{tabular}


Berdasarkan hasil tabel 7 diketahui bahwa responden diet baik sebanyak 19 orang $(38 \%)$ dengan kadar $\mathrm{Hb}$ normal dan tidak baik sebanyak 9 responden (28\%) dengan kadar $\mathrm{Hb}$ normal. Hasil uji statistic dengan chi square didapatkan hasil bahwa nilai $\mathrm{p}=0,462(\mathrm{p}>0,05)$ jadi tidak ada hubungan diet terhadap kenaikan kadar $\mathrm{Hb}$ ibu hamil anemia.

\section{Analisa Multivariat.}

\section{Tabel 8}

Analisa Multivariat

\begin{tabular}{llll}
\hline Variabel & Beta & df & $\mathrm{p}$ \\
\hline Constant & 1,299 & 1 & 0,046 \\
Umur & 0,240 & 1 & 0,087 \\
Gravid & 0,268 & 1 & 0,006 \\
Pendidikan & 0,310 & 1 & 0,001 \\
Pengetahuan & 0,152 & 1 & 0,006 \\
Diet & 0,542 & 1 & 0,840 \\
\hline
\end{tabular}

Berdasarkan tabel di atas maka dapat dilihat bahwa dilihat dari nilai $\mathrm{p}$ maka faktor yang paling berhubungan dengan kenaikan kadar $\mathrm{Hb}$ adalah pendidikan dengan nilai $\mathrm{p}=0,001(\mathrm{p}<0,05)$, kemudian pengetahuan dengan nilai $\mathrm{p}=0,006$ $(p<0,05)$ dan gravida dengan nilai $p=0,006$ $(\mathrm{p}<0,05)$

\section{PEMBAHASAN}

Hal ini terkait dengan Kondisi biologis dan psikologis dari ibu hamil.Sebaliknya pada kelompok umur < 20 tahun beresiko anemia sebab pada kelompok umur tersebut perkembangan bilogis yaitu reproduksi belum optimal. Selain itu, kehamilan pada kelompok usia diatas 35 tahun merupakan kehamilan yang beresiko tinggi. Wanita hamil dengan umur diatas 35 tahun juga akan rentan anemia. Hal ini menyebabkan daya tahun tubuh mulai menurun dan mudah terkena berbagai infeksi selama masa kehamilan (Manuaba, 2007)
Pendidikan yang dijalani seseorang memiliki pengaruh pada peningkatan kemampuan berpikir, dengan kata lain seseorang yang berpendidikan lebih tinggi akan dapat mengambil keputusan yang lebih rasional, umumnya terbuka untuk menerima perubahan atau hal baru dibandingkan dengan individu yang berpendidikan rendah. Tingkat pendidikan ibu hamil yang rendah mempengaruhi penerimaan informasi sehingga pengetahuan tentang anemia dan faktorfaktor yang berhubungan dengannya menjadi terbatas, terutama pengetahuan tentang pentingnya zat besi (Budiono, 2009)

Paritas, Resiko ibu mengalami anemia dalam kehamilan salah satu penyebabnya adalah ibu yang sering melahirkan dan pada kehamilan berikutnya ibu kurang memperhatikan asupan nutrisi yang baik dalam kehamilan. Hal ini disebabkan karena dalam masa kehamilan zat gizi akan terbagi untuk ibu dan untuk janin yang dikandung (Herlina, 2009). Kecenderungan bahwa semakin banyak jumlah kelahiran (paritas), maka akan semakin tinggi angka kejadian anemia (Wahyudin, 2004).

Pengetahuan ibu sangat berpengaruh atas gizi bayi yang dikandungnya dan juga pola konsumsi makanan terutama makanan yang mengandung zat besi, karena apabila kekurangan zat besi pada masa kehamilan dalam waktu yang relatif lama akan menyebabkan terjadinya anemia (Notoatmodjo, 2013).

Penyebab tersering anemia selama kehamilan yaitu defisiensi besi dan kehilangan darah akut. Tidak jarang keduanya saling berkaitan erat, karena pengeluaran darah yang berlebihan disertai hilangnya besi hemoglobin dan terkurasnya simpanan besi pada suatu kehamilan dapat 
menjadi penyebab penting anemia defisiensi besi pada kehamilan berikutnya. Status gizi yang kurang sering berkaitan dengan anemia defisiensi besi (Scholl, 1998). Pada gestasi biasa dengan satu janin, kebutuhan ibu akan besi yang dipicu oleh kehamilannya rata-rata mendekati $800 \mathrm{mg}$; sekitar $500 \mathrm{mg}$; bila tersedia untuk ekspansi massa hemoglobin ibu sekitar $200 \mathrm{mg}$ atau lebih keluar melalui usus, urin dan kulit. Jumlah total ini $1000 \mathrm{mg}$ jelas melebihi cadangan besi pada sebagian besar wanita. Kecuali apabila perbedaan antara jumlah cadangan besi ibu dan kebutuhan besi selama kehamilan normal yang disebutkan diatas dikompensasi oleh penyerapan besi dari saluran cerna, akan terjadi anemia defisiensi besi (Arisman, 2007).

\section{KESIMPULAN DAN SARAN}

A. Kesimpulan

Berdasarkan hasil penelitian didapatkan kesimpulan sebagai berikut

1. Kadar hemoglobin ibu hamil anemia yang diberi MMN rata-rata adalah 10,4 $\mathrm{mmHg}$

2. Kadar hemoglobin ibu hamil anemia yang sebelum diberi sarikurma rata-rata 10,38 dan sesudah diberi sarikurma rata-rata 10,84 .

3. Sarikurma lebih efektif dibandingkan dengan MMN dengan nilai $\mathrm{p}=0,045(\mathrm{p}<0,05)$.

B. Saran

1. Bagi institusi pendidikan

Hasil penelitian ini dapat digunakan sebagai masukan untuk menambah wawasan khususnya tentang kurma terhadap ibu hamil Anemia

2. Bagi penulis

Dapat mengaplikasikan ilmu yang diperoleh dengan memberikan informasi kepada ibu hamil tentang kurma untuk peningkatan kadar Hemoglobin.

3. Bagi profesi Bidan

Sebagai salah satu upaya promotif dan preventif bagi bidan dalam menangani masalah peningkatan hemoglobin ibu hamil.

4. Bagi ibu hamil

Dapat melakukan penanganan pada anemia dengan cara yang lebih alami yaitu dengan konsumsi kurma sehingga meningkatkan kadar Hemoglobin, serta lebih ekonomis dan praktis.

5. Bagi pelayanan kesehatan

Menambah pengalaman bagi pelayanan dalam memberikan metode peningkatan kadar hemoglobin ibu hamil

6. Bagi Peneliti

Sebagai ujud tridarma Perguruan Tinggi

\section{DAFTAR RUJUKAN}

Agustian EN. 2010. Karya Tulis Ilmiah: Hubungan antara Asupan Protein dengan Kekurangan Energi Kronik (KEK) pada Ibu Hamil di Kecamatan Jebres Surakarta. Prodi DIV Kebidanan, Universitas Sebelas Maret, Surakarta.

Al Sahib, Walid, Richard J. Marshall. 2003. The fruit of the date palm: its possible use as the best food for the future.International Journal of Food Sciences and Nutrition, London, p:247-259.

Atmarita. 2006. Makalah Widyakara Nasional Pangan dan Gizi VIII: Analisis Situasi Gizi dan Kesehatan Masyarakat. Direktorat Gizi Masyarakat, Departemen Kesehatan, Jakarta. 
Azwar, Azrul. 2006. Naskah Pertemuan Advokasi Program Perbaikan Gizi Menuju Keluarga Sadar Gizi: Kecenderungan Masalah Gizi dan Tantangan di Masa Datang. Dirjen Bina Kesmas Depkes, Jakarta.

Dinas Kesehatan Kabupaten Klaten. 2015. Laporan Terpadu ANC. Klaten.

Hardiansyah, Briawan D, Sulaeman A, Rimbawan. 2013. Kapasitas Antioksidan Dan Indeks Glikemik Sari Kurma Serta Efikasinya Terhadap Stamina. Semnas Pagi 2013, Biokimia Gizi, Gizi Klinis dan Dietetik.

Himawan AT, Pertiwi D. 2013.Pengaruh Pemberian Sari Kurma (Phoenix dactylifera) terhadap Kadar Hemoglobin Studi Eksperimental pada Tikus Putih Jantan Galur Wistar yang Diberi Diet Rendah Zat Besi (Fe). Sains Medika, Vol. 5, No. 1, Januari - Juni 2013 : 17-19.

Proverawati. 2009. Asuhan Kebidanan Kehamilan. Nuha Medika, Yogyakarta.

Santoso BH. 2008. Tanaman, Ragam, Khasiat Obat. Agromedia Pustaka, Jakarta.

Satuhu, Suyanti. 2010. Kurma, Khasiat dan Olahannya. Sumber Swadaya, Depok.

Sawaya W.N., Khalil J.K., Khatchadourian H.A., Safi W.M. and Mashadi A.S. 1983. Sugar, tannins and some vitamins contents of 25 date cultivars grown in Saudi Arabia at the Khalal (mature color) and Tamer (ripe) Stages. In: Proceedings of the First Symposium on the Date Palm in Saudi Arabia, King Faisal University, Al-Hassa, Riyadh, Saudi Arabia: Mars Publishing House, p: 468-477.

Sugiyono. 2006. Statistika Untuk Penelitian. CV. Alfabeta, Bandung. 